\title{
Plasmid-mediated resistance to gentamicin in Staphylococcus aureus: the involvement of a transposon
}

\author{
B. R. LYON,* M. T. GILLESPIE,† M. E. BYRNE, J. W. MAY and R. A. SKURRAY
}

Department of Microbiology, Monash University, Clayton, Victoria 3168, Australia

\begin{abstract}
Summary. Resistance to gentamicin, tobramycin and kanamycin $\left(\mathrm{Gm}^{\mathrm{r}} \mathrm{Tm}^{\mathrm{r}} \mathrm{Km}^{\mathrm{r}}\right)$ in strains of Staphylococcus aureus isolated from clinical sources in Australia is mediated by a $4.7 \mathrm{~kb}$ transposable element, designated Tn4001. A $2.5 \mathrm{~kb}$ HindIII fragment which maps symmetrically within Tn4001, and encompasses the aminoglycosideresistance coding region, has been shown to hybridise with fragments of identical size in HindIII digests of three different $\mathrm{Gm}^{\mathrm{r}} \mathrm{Tm}^{\mathrm{r}} \mathrm{Km}^{\mathrm{r}}$ plasmids, two of which were selftransmissible, from strains of $S$. aureus isolated in the USA. Examination by electronmicroscopy of self-annealed molecules of the North American $\mathrm{Gm}^{\mathrm{r}} \mathrm{Tm}^{\mathrm{r}} \mathrm{Km}^{\mathrm{r}}$ plasmids revealed the presence of stem and loop structures similar to those produced by $\mathrm{Tn} 4001$, but with shorter inverted repeats. These results suggest that $\mathrm{Gm}^{\mathrm{r}} \mathrm{Tm}^{\mathrm{r}} \mathrm{Km}^{\mathrm{r}}$ in strains of $S$. aureus isolated in the USA is, or once was, transposable, and that transposable elements analogous to Tn4001 may be found in isolates of $\mathrm{Gm}^{\mathrm{r}} \mathrm{Tm}^{\mathrm{r}} \mathrm{Km}^{\mathrm{r}}$ $S$. aureus worldwide.
\end{abstract}

\section{Introduction}

Strains of Staphylococcus aureus resistant to gentamicin were first isolated from clinical sources in the mid-1970's (Soussy et al., 1975; Speller et al., 1976). Since then, numerous outbreaks of gentamicin-resistant $S$. aureus infection have been reported from hospitals around the world (Crossley et al., 1979; Price et al., 1980; Hone et al., 1981; Pavillard et al., 1982).

In staphylococci, resistance to gentamicin, tobramycin and kanamycin is usually mediated by a bifunctional protein that specifies $6^{\prime}$ acetyltransferase [AAC $\left(6^{\prime}\right)$ ] and $2^{\prime \prime}$ phosphotransferase [APH $\left(2^{\prime \prime}\right)$ ] aminoglycoside modifying activities (Martel et al., 1983; Ubukata et al., 1984) and is plasmidencoded in the majority of S. aureus strains (LeGoffic et al., 1977; Scott et al., 1978; Ubukata et al., 1984). Restriction endonuclease analyses of a number of these plasmids have revealed a high degree of structural relatedness, implying a common origin (Jaffe et al., 1982; Gray et al., 1983; Goering

Received 21 Apr. 1986; Accepted 24 June 1986.

* Present address: Department of Genetics, Monash University, Clayton, Victoria 3168, Australia.

$\dagger$ Present address: Research Centre for Cancer and Transplantation, Department of Pathology, University of Melbourne, Parkville, Victoria 3052, Australia.

$\ddagger$ Correspondence and requests for reprints should be sent to Dr R. A. Skurray. and Ruff, 1983). Such plasmids range in size from 18 to 57 kilobases $(\mathrm{kb})$ and may specify resistance to other aminoglycosides through $4^{\prime}$ adenyltransferase [AAD (4')] (Wood et al., 1977; Archer and Johnston, 1983; McDonnell et al., 1983) or APH (3') modification (Gray et al., 1983; Ubukata et al., 1984), mediate penicillin resistance via a $\beta$ lactamase (Cohen et al., 1982; Goering and Ruff, 1983; McDonnell et al., 1983) or carry determinants for resistance to ethidium bromide and quaternary ammonium compounds $\left(\mathrm{Eb}^{\mathrm{r}} \mathrm{Qa}^{\mathrm{r}}\right)$ (Asch et al., 1984).

Several of the larger plasmids promote their own transfer, and mobilise non-transferable plasmids, by a process analogous to conjugation (Archer and Johnston, 1983; McDonnell et al., 1983; Asch et al., 1984).

Australian strains of $\mathrm{Gm}^{\mathrm{r}} \mathrm{Tm}^{\mathrm{r}} \mathrm{Km}^{\mathrm{r}} \quad$ S. aureus manifest a family of structurally related plasmids that uniformly encode resistance to acriflavine, ethidium bromide and quaternary ammonium compounds $\left(\mathrm{Ac}^{\mathrm{r}} \mathrm{Eb}^{\mathrm{r}} \mathrm{Qa}^{\mathrm{r}}\right)$, but may also specify $\mathrm{Gm}^{\mathrm{r}} \mathrm{Tm}^{\mathrm{r}} \mathrm{Km}^{\mathrm{r}}$, resistance to trimethoprim $\left(\mathrm{Tp}^{\mathrm{r}}\right)$ and $\beta$-lactamase production (Lyon et al., 1983; Lyon et al., 1984a; Gillespie and Skurray, 1986). Previous studies indicate that $\mathrm{Gm}^{\mathrm{r}} \mathrm{Tm}^{\mathrm{r}} \mathrm{Km}^{\mathrm{r}}$ is encoded by a transposable element designated Tn4001 (Lyon et $a l ., 1984 b$ ).

In this paper, we compare the regions encoding $\mathrm{Gm}^{\mathrm{r}} \mathrm{Tm}^{\mathrm{r}} \mathrm{Km}^{\mathrm{r}}$ from three distinct plasmids isolated in the USA with Tn4001, using restriction endonu- 
clease analysis, DNA-DNA hybridisation and electronmicroscopy to examine the possibility that the one transposon has been responsible for the widespread outbreaks of $\mathrm{Gm}^{\mathrm{r}} \mathrm{Tm}^{\mathrm{r}} \mathrm{Km}^{\mathrm{r}}$ in $S$. aureus.

\section{Materials and methods}

\section{Bacterial strains and plasmids}

All $S$. aureus $\mathrm{Gm}^{\mathrm{r}}$ plasmids were transferred from clinical isolates to the laboratory strains SK 982 (rifampicin and novobiocin resistant; $\mathbf{R f}^{\mathrm{r}}, \mathrm{Nv}^{\mathrm{r}}$ ) (Lyon et al., $1984 b$ ) or SK 983 (streptomycin and fusidic acid resistant; $\mathrm{Sm}^{\mathrm{r}}, \mathrm{Fa}^{\mathrm{r}}$ )(Tennent et al., 1985). The plasmids used, along with relevant characteristics, are listed in table I.

\section{General methods}

Standard culture media and methods for the determination of antimicrobial susceptibilities and minimum inhibitory concentrations (MICs) were as previously described (Lyon et al., 1983; Tennent et al., 1985).

\section{Plasmid transfer}

Mixed-culture transfer and filter matings were conducted essentially as described by McDonnell et al. (1983). Resistant progeny in transfers with the recipient strains SK982 or SK983 were selected on Brain Heart Infusion Agar (Oxoid) containing $(\mu \mathrm{g} / \mathrm{ml}) \mathrm{Gm} 8$ and $\mathrm{Rf}$ $10, \mathrm{Nv} 1$ or $\mathrm{Sm} 100, \mathrm{Fa} 10$, respectively.

\section{Plasmid DNA isolation, restriction analysis and cloning procedures}

The isolation of purified plasmid DNA from $S$. aureus cultures, digestion with the restriction endonucleases $B g I I I, E c o$ RI, HaeIII, HindIII and PvuII (New England Biolabs), agarose gel electrophoresis, and the estimation of DNA fragment sizes were performed as published (Lyon et al., 1983). HindIII digests of lambda $(\lambda)$ virus DNA (Miles Laboratories) were employed as standards with fragment sizes (in $\mathrm{kb}$ ) taken from Daniels et al. (1983). The procedure for E. coli plasmid DNA isolation, together with all recombinant DNA techniques, have been described previously (Ray and Skurray, 1983).

\section{DNA-DNA hybridisation}

DNA was transferred to nitrocellulose filters by the bidirectional transfer procedure of Smith and Summers (1980). DNA for use as a radiolabelled probe was electroeluted from an agarose gel (Smith, 1980) and nick translated with $\left[\alpha^{32} \mathrm{P}\right]$ dATP essentially as described by Maniatis et al. (1982). Hybridisation was conducted in the presence of formamide $50 \%, 5 \times$ SSC $(1 \times$ SSC was $0 \cdot 15 \mathrm{M} \mathrm{NaC} 1,0 \cdot 015 \mathrm{M}$ sodium citrate), SDS $0.1 \% \mathrm{w} / \mathrm{v}$ and
Denhardt's solution $2 \%$ (Maniatis et al., 1982) at $45^{\circ} \mathrm{C}$ for $16 \mathrm{~h}$. Hybridised filters were washed at least five times in $4 \times \mathrm{SSC}$, SDS $0.1 \% \mathrm{w} / \mathrm{v}$, dried, and exposed to XOmat-AR X-ray film (Kodak) with an intensifying screen for $24-48 \mathrm{~h}$ at $-70^{\circ} \mathrm{C}$.

\section{Electronmicroscopy}

Self-annealed molecules were formed from purified plasmid DNA and mounted for electronmicroscopy essentially as described by Davis et al. (1971). Molecules were visualised and photographed using a Philips EM 300 at $\times 20000$. Plasmid pC194 $(2.91 \mathrm{~kb}$; Horinouchi and Weisblum, 1982) was cleaved at the single HindIII site and included as a double-stranded size standard, and $\phi X 174$ viral DNA (New England Biolabs, $5.375 \mathrm{~kb}$; Sanger et al., 1977) was used as a single-stranded size standard. Contour lengths (expressed as an average with standard deviation in $\mathrm{kb}$ ) were determined by measurement of photographic enlargements with a MOP-1 digital analyser (Carl Zeiss).

\section{Results}

\section{Physical and genetic analysis of an Australian $\mathrm{Gm}^{r} \mathrm{Tm}^{r} \mathrm{Km}^{r}$ plasmid}

Plasmid pSK1 is the prototype of a family of structurally related plasmids detected in strains of $\mathrm{Gm}^{\mathrm{r}} \mathrm{Tm}^{\mathrm{r}} \mathrm{Km}^{\mathrm{r}}$ S. aureus isolated from Australian hospitals (Lyon et al., 1983; Lyon et al., 1984a). Transfer of pSK1 to SK982 in mixed cultures has revealed that pSK1 encodes $\mathrm{Ac}^{\mathrm{r}} \mathrm{Eb}^{\mathrm{r}} \mathrm{Qa}^{\mathrm{r}}, \mathrm{Gm}^{\mathrm{r}}$ $\mathrm{Tm}^{\mathrm{r}} \mathrm{Km}^{\mathrm{r}}$ and $\mathrm{Tp}^{\mathrm{r}}$ (table I), and comparative restriction mapping of this plasmid with other members of the plasmid family has enabled the construction of a physical-genetic map as illustrated in fig. 1. The genetic determinant for $\mathrm{Gm}^{\mathrm{r}} \mathrm{Tm}^{\mathrm{r}} \mathrm{Km}^{\mathrm{r}}$ has been mapped by comparison with the $\mathrm{Gm}^{\mathrm{s}}$ $\mathrm{Tm}^{\mathrm{s}} \mathrm{Km}^{\mathrm{s}}$ plasmid pSK7 (table I), which was found to be identical to pSK 1 except that it does not possess the $4 \cdot 7-\mathrm{kb}^{\mathrm{r}} \mathrm{Gm}^{\mathrm{r}} \mathrm{Tm}^{\mathrm{r}} \mathrm{Km}^{\mathrm{r}}$ transposon, Tn4001 (fig. 1).

A $2 \cdot 5-\mathrm{kb}$ HindIII fragment, which maps symmetrically within Tn4001 and is believed to encompass the gene(s) for $\mathrm{Gm}^{\mathrm{r}} \mathrm{Tm}^{\mathrm{r}} \mathrm{Km}^{\mathrm{r}}$ (fig. 1), has been cloned from pSK 31, a Tn4001-inserted derivative of pII147 (Lyon et al., 1984b), into the unique $H$ indIII site in the $E$. coli vector plasmid pACYC184 (fig. 2). The resulting recombinant plasmid, designated pSK310, mediates $\mathrm{Gm}^{\mathrm{r}}$ $\mathrm{Tm}^{\mathrm{r}} \mathrm{Km}^{\mathrm{r}}$ in the E. coli host, thus confirming the location of the aminoglycoside resistance determinant on the $2 \cdot 5-\mathrm{kb}$ HindIII fragment. Digestion of pSK310 with HindIII (fig. 3A, lane c) revealed a fragment with identical mobility to that of the $2 \cdot 5$ - 
pSK1

pSK7
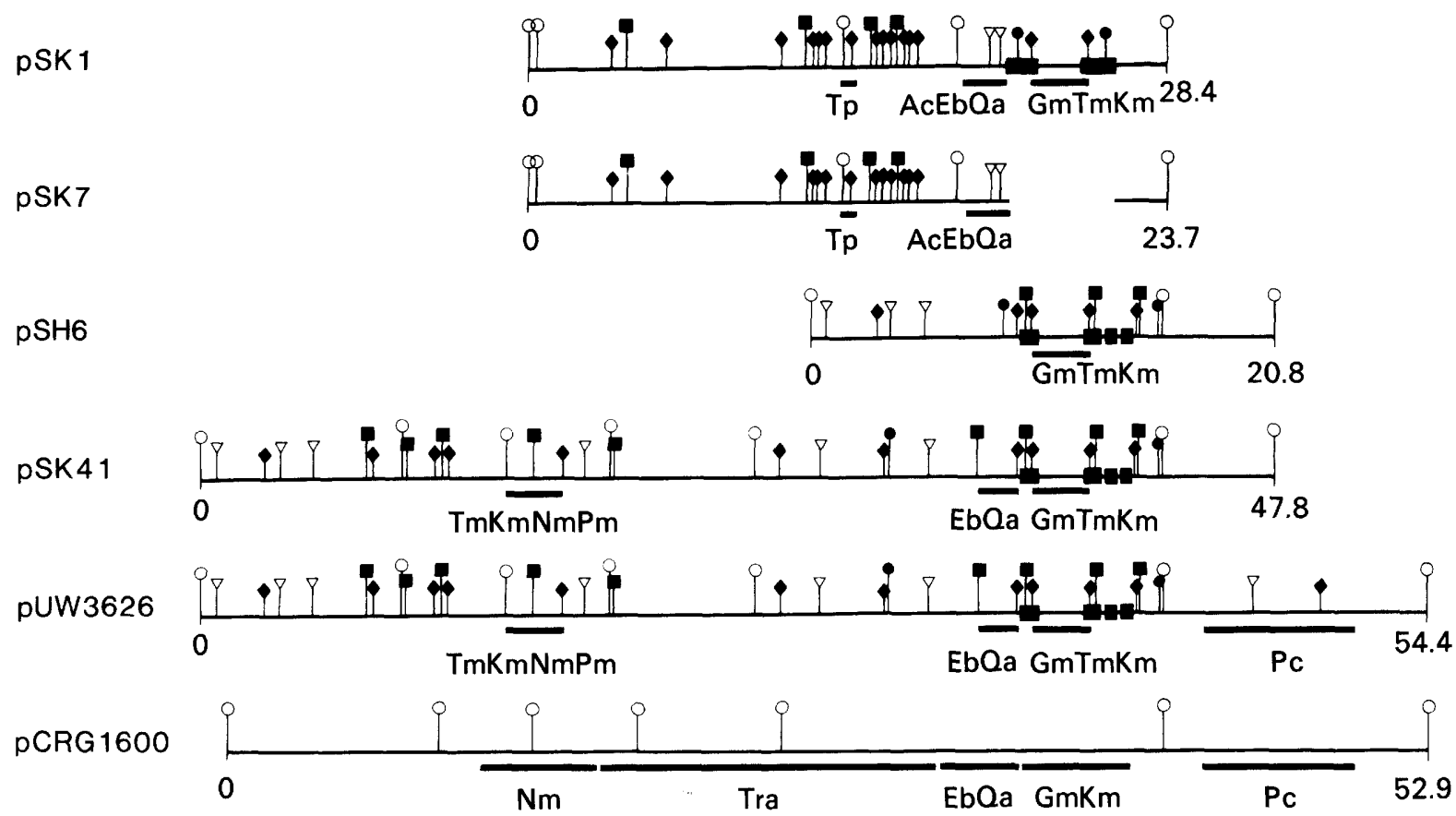

Fig. 1. Linear restriction maps of the plasmids pSK1, pSK 7, pSH6, pSK41, pUW3626 and pCRG1600. These maps, with the exception of that for pSK 7, are aligned relative to the common $2 \cdot 5-\mathrm{kb}$ HindIII fragment within the $\mathrm{Gm}^{\mathrm{r}} \mathrm{Tm}^{\mathrm{r}} \mathrm{Km}^{\mathrm{r}}$ region; the map for pSK 7 is aligned to that of pSK 1 ; coordinates are in $\mathrm{kb}$. Restriction endonuclease sites are indicated by $\square(B g 1 \mathrm{II}), \mathrm{O}(E c o \mathrm{RI})$, (HindIII), (HaeIII) and $\nabla$ (PvuII); only relevant HaeIII sites are shown. Gm, Tm, Km, Ac, Eb, Qa, Tp, Nm, Pm and Pc designate the plasmid DNA segments that mediate resistance to gentamicin, tobramycin, kanamycin, acriflavine, ethidium bromide, quaternary ammonium compounds, trimethoprim, neomycin, paromomycin and penicillin, respectively. Tra indicates the DNA segment that mediates plasmid self-transmissibility. Inverted repeats are represented by the thick lines. The map of pCRG1600 is adapted from Asch et al. (1984); it should be noted that although the sizes of the EcoRI fragments as used by the latter authors to map pCRG1600 differ from those we have determined for pUW3626, both plasmids appear to possess five, out of six, common-sized EcoRI fragments (Goering and Ruff, 1983).

kb HindIII fragment of pSK1 (fig. 3A, lane b) together with the $4 \cdot 2-\mathrm{kb}$ HindIII linear fragment of pACYC184. When the $2 \cdot 5-\mathrm{kb}$ HindIII fragment of pSK 310 was used as a radiolabelled probe, it was found to hybridise to itself (fig. 3B, lane c) and to the $2 \cdot 5-\mathrm{kb}$ HindIII fragment of pSK 1 (fig. 3B, lane b), thus confirming the identity of these fragments.

\section{Physical and genetic analysis of North American $\mathrm{Gm}^{r} \mathrm{Tm}^{r} \mathrm{Km}^{r}$ plasmids}

The three plasmids pSK 41, pSH6 and pUW 3626 (see table I for details) were transferred to the recipient strains SK982 or SK983 to enable their further characterisation. Plasmid pSH6 was found,

Table I. Staphylococcus aureus plasmids and their characteristics

\begin{tabular}{|c|c|c|c|c|c|}
\hline Plasmid & Phenotype & $\begin{array}{l}\text { Modifying } \\
\text { enzymes }\end{array}$ & $\begin{array}{l}\text { Size } \\
(\mathrm{kb})\end{array}$ & $\begin{array}{l}\text { Clinical } \\
\text { isolate* }\end{array}$ & Reference \\
\hline pSK 1 & $G m^{r} T m^{r} K m^{r} A c^{r} E b^{r} Q a^{r} T p^{r}$ & ND & $28 \cdot 4$ & SK529 & Lyon et al., 1983, 1986 \\
\hline pSK 7 & $A c^{r} E b^{r} Q^{r} T p^{r}$ & ND & $23 \cdot 7$ & SK460 & Lyon et al., 1984a \\
\hline pSK41 & $\mathrm{Gm}^{\mathrm{r}} \mathrm{Tm}^{\mathrm{r}} \mathrm{Km}^{\mathrm{r}} \mathrm{Nm}^{\mathrm{r}} \mathrm{Pm}^{\mathrm{r}} \mathrm{Eb}^{\mathrm{r}} \mathrm{Qa}^{\mathrm{r}} \mathrm{Tra}^{+}$ & $\mathrm{AAC}\left(6^{\prime}\right) \mathrm{APH}\left(2^{\prime \prime}\right) \mathrm{AAD}\left(4^{\prime}\right)$ & $47 \cdot 8$ & Spratlin & Wood et al., 1977 \\
\hline pSH6 & $\mathrm{Gm}^{\mathrm{r}} \mathrm{Tm}^{\mathrm{r}} \mathrm{Km}^{\mathrm{r}}$ & $\mathrm{AAC}\left(6^{\prime}\right) \mathrm{APH}\left(2^{\prime \prime}\right)$ & $20 \cdot 8$ & SH6 & McDonnell et al., 1983 \\
\hline pUW 3626 & $\mathrm{Gm}^{\mathrm{r}} \mathrm{Tm}^{\mathrm{r}} \mathrm{Km}^{\mathrm{r}} \mathrm{Nm}^{\mathrm{r}} \mathrm{Pm}^{\mathrm{r}} \mathrm{Eb}^{\mathrm{r}} \mathrm{Qa}^{\mathrm{r}} \mathrm{Pc}^{\mathrm{r}} \mathrm{Tra}^{+}$ & ND & $54 \cdot 4$ & L3626 & Cohen et al., 1982 \\
\hline
\end{tabular}

ND; not determined.

* We are grateful to G. K. Best, Medical College of Georgia, USA, S. Cohen, University of Chicago, USA and M. L. Cohen, Center for Infectious Diseases, Atlanta, USA for providing strains Spratlin, SH6 and L3626, respectively. 


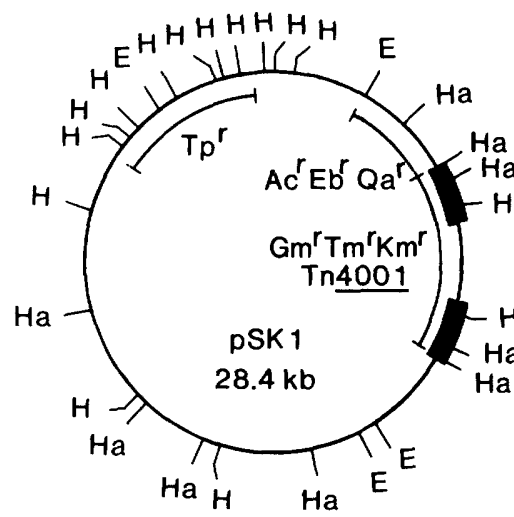

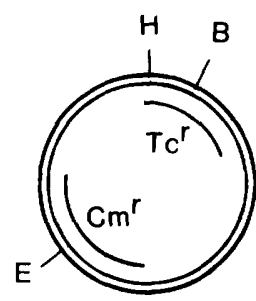

PACYC 184

$4.2 \mathrm{~kb}$ transposition

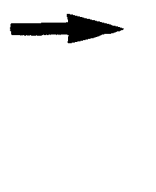

chromosome::Tnuuㅗ transposition

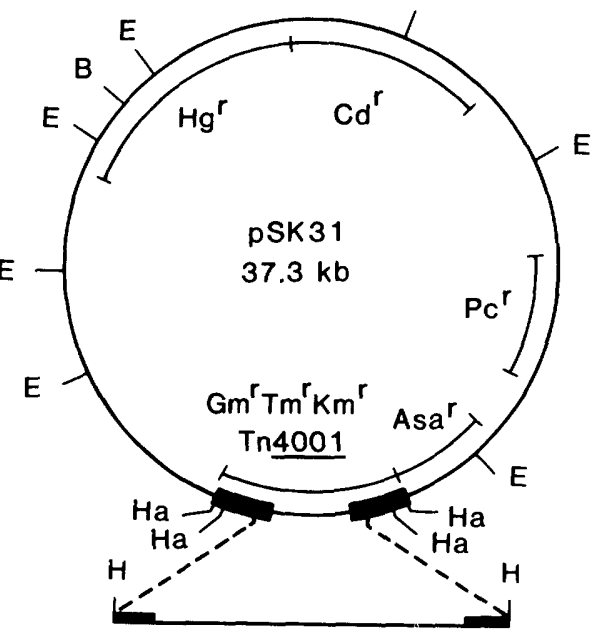

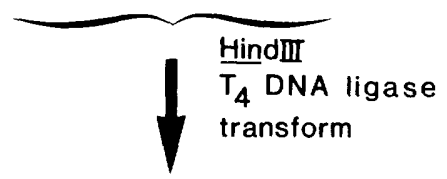

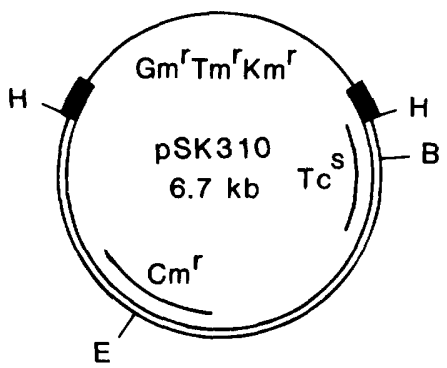

Fig. 2. Strategy for cloning the central coding region of Tn4001. A simplified restriction map of the 28.4-kb $A c^{r} E b^{r} Q a^{r}, T p^{r}$ and $\mathrm{Gm}^{\mathrm{r}} \mathrm{Tm}^{\mathrm{r}} \mathrm{Km}^{\mathrm{r}}$ plasmid pSK1 showing the inverted repeats of the $4 \cdot 7-\mathrm{kb}$ aminoglycoside resistance transposon Tn 4001 (thick lines). During mixed-culture transfer experiments, Tn4001 was transposed to the chromosome of a strain which carried the 32.6-kb penicillin (Pc), arsenate (Asa), cadmium (Cd) and mercury (Hg) resistance plasmid pII147 (Shalita et al., 1980), constructing the strain SK2230. A bacteriophage 80 $\alpha$ lysate was prepared from SK2230 and used to transduce $S$. aureus strain NCTC 8325 for resistance to gentamicin and cadmium. One such plasmid resulting from this transduction was pSK31, which arose from the transposition of Tn 4001 from the $S$. aureus chromosome to pII147. Purified pSK31 DNA was digested with HindIII and "shotgun" cloned into the HindIII site of the $E$. coli vector pACYC184 (double open lines) to produce the chloramphenicol-resistant $\left(\mathrm{Cm}^{\mathrm{r}}\right)$ and tetracycline-sensitive $\left(\mathrm{Tc}^{\mathrm{s}}\right)$ 6.7-kb plasmid pSK310. Restriction endonuclease sites are indicated by B (BamHI), E (Eco RI), Ha (HaeIII), and H (HindIII); only the relevant HaeIII sites are shown. 


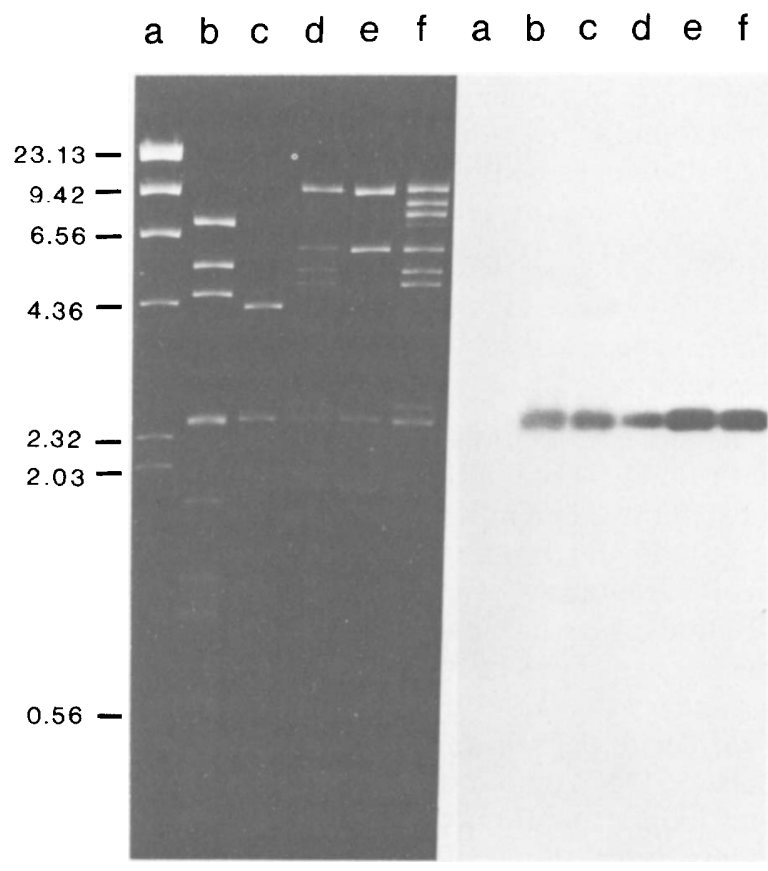

A

B

Fig. 3. (A) Agarose gel $(1 \cdot 2 \% \mathrm{w} / \mathrm{v})$ electrophoresis of purified $S$. aureus and $E$. coli plasmid DNA cleaved with $H$ indIII. Lane a, $\lambda$ virus DNA cleaved with HindIII, fragment sizes (in $\mathrm{kb}$ ) are shown at left; b, pSK1; c, pSK310; d, pSK41; e, pSH6; f, pUW3626. (B) DNA from the above gel transferred to nitrocellulose and hybridised with a ${ }^{32} \mathrm{P}$ nick-translated probe consisting of the $2 \cdot 5-\mathrm{kb}$ HindIII fragment from pSK 310 .

like the pSK1-related plasmids, to readily transfer to SK 982 in broth mixed cultures, however pSK 41 and pUW3626 failed to transfer under these conditions. The latter two plasmids did, however, transfer to SK983 at high frequency in filter matings, a result consistent with these plasmids being self-transmissible ( $\mathrm{Tra}^{+}$; McDonnell et al., 1983). Indeed, pUW3626 has previously been reported to be Tra $^{+}$(Goering and Ruff, 1983).

All three plasmids were shown to encode $\mathrm{Gm}^{\mathrm{r}}$ $\mathrm{Tm}^{\mathrm{r}} \mathrm{Km}^{\mathrm{r}}$, a phenotype which in the case of pSK41 and pSH6 is mediated by AAC $\left(6^{\prime}\right)$ and APH (2") activities (Scott et al., 1978; Vogel et al., 1978). Plasmids pSK41 and pUW3626 also encoded resistance to neomycin $\left(\mathrm{Nm}^{\mathrm{r}}\right)$ and paromomycin $\left(\mathrm{Pm}^{\mathrm{r}}\right)$, a phenotype presumed to be mediated by the AAD $\left(4^{\prime}\right)$ activity of pSK41 (Scott et al., 1978), and to ethidium bromide and quaternary ammonium compounds. Plasmid pUW3626 additionally mediated $\mathrm{Pc}^{\mathrm{r}}$ via a $\beta$ lactamase (table I).

The minimum inhibitory concentrations (MICs) of gentamicin, tobramycin and kanamycin were 32,64 and $256 \mu \mathrm{g} / \mathrm{ml}$, respectively, for pSK 41 and pUW3626, while pSH6 gave MICs of 128, 64 and $512 \mu \mathrm{g} / \mathrm{ml}$. These results compare with MICs of 32, 16 and $256 \mu \mathrm{g} / \mathrm{ml}$ for the three aminoglycosides with strain SK982 containing pSK1. The MICs of ethidium bromide, benzalkonium chloride and cetyltrimethylammonium bromide were 40,6 and $4 \mu \mathrm{g} / \mathrm{ml}$, respectively, for pSK41 and pUW3626, compared with 180,6 and $4 \mu \mathrm{g} / \mathrm{ml}$ for $\mathrm{pSK} 1$. Unlike pSK 1 , plasmids pSK41, pSH6 and pUW3626 did not mediate resistance to acriflavine or trimethoprim.

Digestion with the restriction endonucleases EcoRI (data not presented) and HindIII revealed similarities amongst the North American plasmids. Plasmids pSK41 (fig. 3A, lane d) and pUW3626 (fig. 3A, lane f) possessed up to nine HindIII fragments of common size, while pSH6 (fig. 3A, lane e) had at least six fragments in common with the other two plasmids. All three North American plasmids possessed a HindIII fragment of identical electrophoretic mobility to the $2 \cdot 5-\mathrm{kb}$ HindIII fragment of pSK 1 and pSK 310 (fig. 3A, lanes $b$ and c). As this fragment contains the $\mathrm{Gm}^{\mathrm{r}} \mathrm{Tm}^{\mathrm{r}} \mathrm{Km}^{\mathrm{r}}$ encoding region of $\mathrm{Tn} 4001$, the possibility that the same fragment exists in the North American plasmids was tested by probing the digests with the $2 \cdot 5-\mathrm{kb} H$ indIII fragment of pSK 310 . The probe was shown to hybridise the $2 \cdot 5-\mathrm{kb}$ HindIII fragments of each of the North American plasmids (fig. 3B, lanes $\mathrm{d}$, e and $\mathrm{f}$ ), thereby indicating that $\mathrm{Gm}^{\mathrm{r}} \mathrm{Tm}^{\mathrm{r}} \mathrm{Km}^{\mathrm{r}}$ in both Australian and North American isolates of $S$. aureus may be encoded by the same genetic determinant.

Physical maps of pSH6, pSK41 and pUW3626 were prepared by analysis of restriction digests of the three plasmids (fig. 1). The maps were aligned relative to one another and to the map of pSK 1 by use of the common $2 \cdot 5-\mathrm{kb}$ HindIII fragment associated with $\mathrm{Gm}^{\mathrm{r}} \mathrm{Tm}^{\mathrm{r}} \mathrm{Km}^{\mathrm{r}}$ in each plasmid. From this comparison it became obvious that pSH6, pSK41 and pUW3626 were structurally related to each other and to the previously characterised 52.9-kb plasmid pCRG1600 (Asch et al., 1984) which was also isolated in the USA (fig. 1). Use of DNA probes specific for the determinants of $\mathrm{Tm}^{\mathrm{r}} \mathrm{Km}^{\mathrm{r}} \mathrm{Nm}^{\mathrm{r}} \mathrm{Pm}^{\mathrm{r}}, \mathrm{Eb}^{\mathrm{r}} \mathrm{Qa}^{\mathrm{r}}$ and $\mathrm{Pc}^{\mathrm{r}}$, indicated that the regions associated with these resistances in pSK41 and pUW3626 are consistent with the locations of the analogous resistance determinants on pCRG1600 (fig. 1), further testifying to the relatedness of the North American plasmids (M. Gillespie, J. May and R. Skurray, unpublished data). 


\section{Comparison of the $\mathrm{Gm}^{r} \mathrm{Tm}^{r} \mathrm{Km}^{r}$ encoding regions}

The $\mathrm{Gm}^{\mathrm{r}} \mathrm{Tm}^{\mathrm{r}} \mathrm{Km}^{\mathrm{r}}$ encoding region from the plasmids isolated in the USA was subjected to more extensive analysis to determine if it comprises a transposable element such as Tn 4001 .

Restriction mapping of pSK1 has revealed the presence of recognition sites for HaeIII within the inverted repeats of $\mathrm{Tn} 4001$ that result in a unique 3.9-kb HaeIII fragment which maps symmetrically within the transposon (fig. 1). The North American plasmids did not possess this fragment, a finding that was verified by hybridisation with the Tn4001specific probe (data not presented); the $2 \cdot 5-\mathrm{kb}$ HindIII fragment of pSK 310 hybridised to an 11.7$\mathrm{kb}$ HaeIII fragment of both pSK41 and pUW3626, while in the HaeIII digest of pSH6, it hybridised with a $6 \cdot 6-\mathrm{kb}$ HaeIII fragment. The respective HaeIII fragments have been mapped on the three North American plasmids and the HaelII sites were found to be located well outside the positions expected if they were present in Tn4001-like inverted repeats (fig. 1). Further evidence which suggests that the $\mathrm{Gm}^{\mathrm{r}} \mathrm{Tm}^{\mathrm{r}} \mathrm{Km}^{\mathrm{r}}$ region of the North American plasmids differs from Tn4001 resulted from the restriction mapping of the plasmids with BgIII. The North American plasmids possessed symmetrical $B g l$ II sites, on either side of the $\mathrm{Gm}^{\mathrm{r}} \mathrm{Tm}^{\mathrm{r}} \mathrm{Km}^{\mathrm{r}}$ encoding region, which produced a unique $3 \cdot 15$-kb $B g l$ II fragment, whereas no $B g 1$ II sites were shown to be present in Tn4001 (fig. 1).

To investigate if there was any homology between the inverted repeats of Tn 4001 and the flanking sequences of the North American $\mathrm{Gm}^{\mathrm{r}} \mathrm{Tm}^{\mathrm{r}} \mathrm{Km}^{\mathrm{r}}$ determinant, HindIII digests of the North American plasmids were probed with a $0.7-\mathrm{kb}$ HaeIII$H$ indIII fragment derived from the inverted repeat of Tn4001 (data not presented). The 0.5- and 1.9-kb HindIII fragments which, in these three plasmids, map on either side of the $2 \cdot 5-\mathrm{kb}$ $\mathrm{Gm}^{\mathrm{r}} \mathrm{Tm}^{\mathrm{r}} \mathrm{Km}^{\mathrm{r}}$-associated HindIII fragment (fig. 1), were found to hybridise with this probe, suggesting that sequences homologous to the inverted repeat of $\mathrm{Tn} 4001$ are present in the $\mathrm{Gm}^{\mathrm{r}} \mathrm{Tm}^{\mathrm{r}} \mathrm{Km}^{\mathrm{r}}$ region of these North American plasmids.

\section{Electronmicroscopy analysis of the $\mathrm{Gm}^{r} \mathrm{Tm}^{r} \mathrm{Km}^{r}$ plasmids}

Because restriction mapping and hybridisation with the $2 \cdot 5-\mathrm{kb}$ HindIII fragment of pSK 310 had located the $\mathrm{Gm}^{\mathrm{r}} \mathrm{Tm}^{\mathrm{r}} \mathrm{Km}^{\mathrm{r}}$ determinant to the second largest EcoRI fragment of pSK1 and the largest EcoRI fragments of each of the North American plasmids, we examined self-annealed molecules of the relevant EcoRI fragments for the production of secondary structures by electronmicroscopy.

Molecules of self-annealed, EcoRI cleaved pSK1 plasmid DNA demonstrated the characteristic stem and loop structure of Tn4001 (fig. 4A). Measurements of four molecules determined that the 4.74$\mathrm{kb}$ transposon comprised a $1 \cdot 37-\mathrm{kb}$ double-stranded stem and a $2 \cdot 0-\mathrm{kb}$ single-stranded loop (table II). Examples of self-annealed molecules formed from pSK41 and pSH6 DNA are illustrated in figs. 4B and $4 C$, respectively. Such molecules exhibited a long single-stranded region of DNA from end (a) and a shorter single-stranded segment of DNA from end (b), interrupted by two stem and loop structures, marked (c) and (d), separated by a short single stranded link. The average contour length measurements of self-annealed molecules of pSK 41, pSH6 and pUW3626 are presented in table II. These measurements indicate that the singlestranded loop marked (c) is comparable in size to the loop formed by Tn4001, but that the length of

Table II. Contour length measurements of self-annealed DNA from $\mathrm{Gm}^{\mathrm{r}} \mathrm{Tm}^{\mathrm{r}} \mathrm{Km}^{\mathrm{r}}$ plasmids

\begin{tabular}{|c|c|c|c|c|}
\hline \multirow[b]{2}{*}{ Feature } & \multicolumn{4}{|c|}{ Plasmid size* } \\
\hline & pSK1 & pSK41 & pSH6 & pUW3626 \\
\hline SS end (a) to DS stem (c) & $2 \cdot 34 \pm 0 \cdot 06$ & $11 \cdot 33 \pm 0 \cdot 27$ & $9.85 \pm 0.88$ & $10 \cdot 63 \pm 0.78$ \\
\hline DS stem (c) & $1.37 \pm 0.05$ & $0.76 \pm 0.03$ & $0.69 \pm 0 \cdot 11$ & $0.73 \pm 0.13$ \\
\hline SS loop (c) & $2 \cdot 00 \pm 0.14$ & $2 \cdot 09 \pm 0 \cdot 17$ & $2 \cdot 33 \pm 0.12$ & $2.05 \pm 0.25$ \\
\hline SS link between (c) and (d) & \pm & $0 \cdot 15$ & 0.02 & $0 \cdot 15$ \\
\hline DS stem (d) & - & $0.57 \pm 0.08$ & $0.55 \pm 0.04$ & $0.65 \pm 0.09$ \\
\hline SS loop (d) & - & $0 \cdot 20$ & 0.20 & 0.20 \\
\hline DS stem (d) to SS end (b) & $2 \cdot 29 \pm 0.06$ & $1 \cdot 58 \pm 0 \cdot 24$ & $1.62 \pm 0.22$ & $1 \cdot 61 \pm 0.25$ \\
\hline
\end{tabular}

SS, single-stranded DNA; DS, double-stranded DNA; (a), (b), (c), (d) refer to the features indicated in fig. 4 .

* Measurements are in $\mathrm{kb}$; at least four molecules were measured for each feature. 

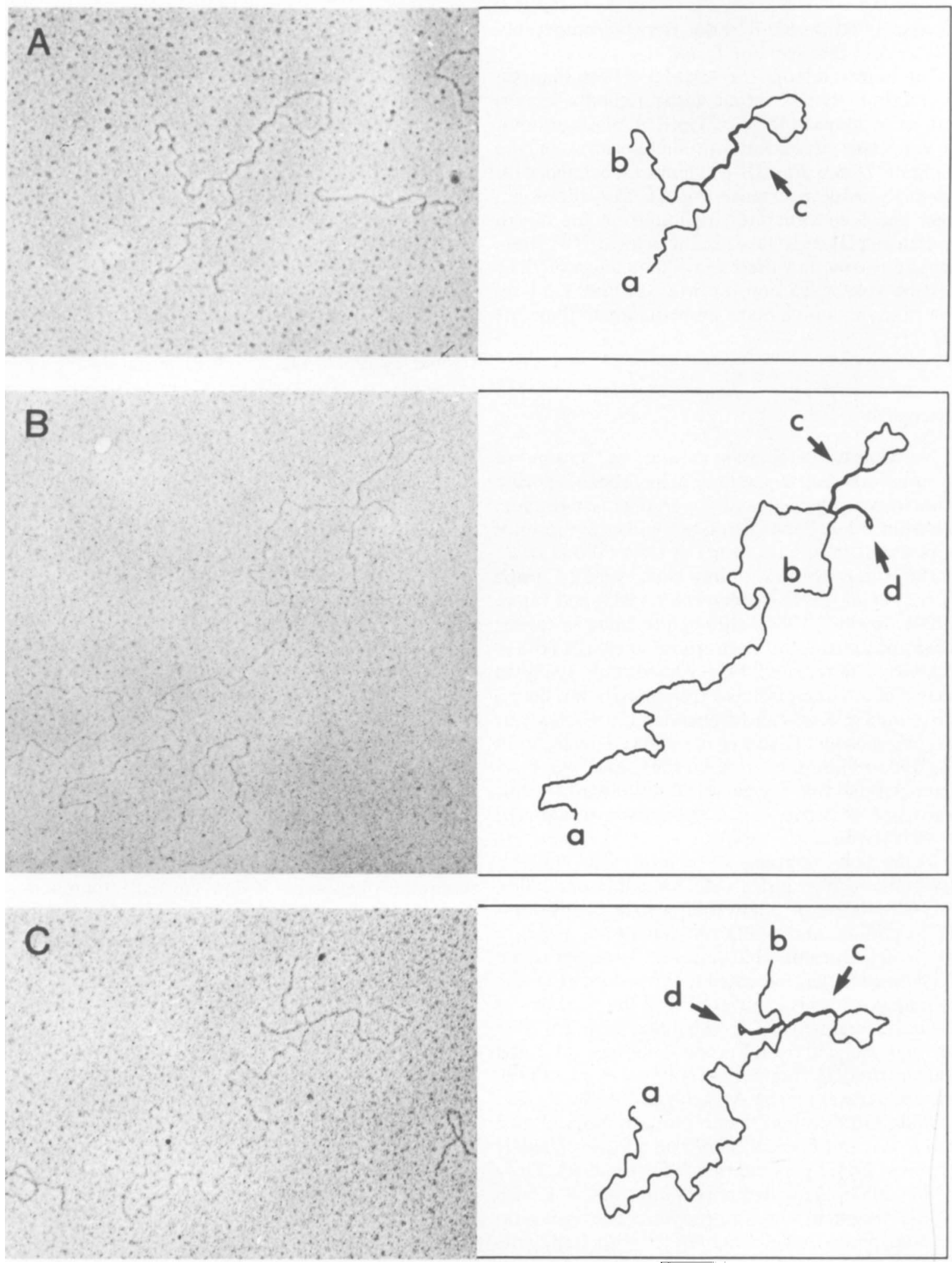

Fig. 4. Electronmicrographs of A, pSK1; B, pSK 41; C, pSH6 plasmid DNA which had been cleaved with EcoRI and treated to enhance the formation of secondary structures. Tracings of each molecule are located at right for easier interpretation. The ends of each molecule are denoted by (a) and (b). The arrow marked (c) indicates a structure with a large single-stranded loop; the arrow marked (d) indicates a structure with a small single-stranded loop. 
the associated double-stranded stem is considerably shorter than that seen for Tn 4001 .

The stem and loop structures have been mapped by relating their contour measurements to the restriction maps of the $\mathrm{Gm}^{\mathrm{r}} \mathrm{Tm}^{\mathrm{r}} \mathrm{Km}^{\mathrm{r}}$ plasmids and, as expected, correspond to the position of the common $2 \cdot 5-\mathrm{kb}$ HindIII fragment associated with aminoglycoside resistance (fig. 1). The additional stem and loop structures (d) found on the North American plasmids have also been located on these physical maps, but there is no indication of their possible role or relationship with the $\mathrm{Gm}^{\mathrm{r}} \mathrm{Tm}^{\mathrm{r}} \mathrm{Km}^{\mathrm{r}}$ determinant, which maps immediately to their left (fig. 1).

\section{Discussion}

Nosocomial infections caused by strains of $S$. aureus resistant to gentamicin have been reported with increasing frequency over the past decade. Resistance has been correlated with the presence of plasmids in isolates from the USA (Wood et al., 1977; Jaffe et al., 1982; Gray et al., 1983), Europe (Soussy et al., 1975; Naidoo et al., 1983) and Japan (Ubukata et al., 1984), although in some instances a chromosomal locus seems more likely (El Solh et al., 1981; Kayser et al., 1981 ; Dowd et al., 1983). In strains of $S$. aureus isolated from Australian hospitals, $\mathrm{Gm}^{\mathrm{r}} \mathrm{Tm}^{\mathrm{r}} \mathrm{Km}^{\mathrm{r}}$ can be encoded on plasmids or the chromosome (Lyon et al., 1983; Townsend et al., 1983; Gillespie et al., 1984), and we have demonstrated that the genetic determinant for this resistance is carried by a transposon designated Tn4001 (Lyon et al., 1984b).

Restriction mapping of several $\mathrm{Gm}^{\mathrm{r}} \mathrm{Tm}^{\mathrm{r}} \mathrm{Km}^{\mathrm{r}}$ plasmids, such as pSH8 (McDonnell et al., 1983), a 45-kb relative of pSH6 that is structurally similar to pSK41, and pG02 (Archer et al., 1985), a 50 -kb self-transmissible plasmid isolated from $S$. epidermidis, has indicated that resistance to these aminoglycosides is associated with the presence of a HindIII fragment of $c .2 \cdot 4-\mathrm{kb}$ in size. $\mathrm{Gm}^{\mathrm{r}} \mathrm{Tm}^{\mathrm{r}} \mathrm{Km}^{\mathrm{r}}$ plasmids isolated from European sources exhibited similar HindIII fragments (Naidoo et al., 1983), and the gene(s) for the AAC $\left(6^{\prime}\right)$ and $\mathrm{APH}\left(2^{\prime \prime}\right)$ that mediate $\mathrm{Gm}^{\mathrm{r}} \mathrm{Tm}^{\mathrm{r}} \mathrm{Km}^{\mathrm{r}}$ has reportedly been cloned into E. coli and Bacillus subtilis on a 2·3-kb HindIII fragment from a plasmid isolated in the USA (Gray et al., 1983). The demonstration that a $2 \cdot 5-\mathrm{kb}$ $H$ indIII fragment which maps symmetrically within the transposon Tn 4001 hybridises with fragments of identical size in HindIII digests of three different North American plasmids, implies that the determinants of $\mathrm{Gm}^{\mathrm{r}} \mathrm{Tm}^{\mathrm{r}} \mathrm{Km}^{\mathrm{r}}$ carried by Australian and
North American plasmids are homologous. Like the Australian determinant, the $\mathrm{Gm}^{\mathrm{r}} \mathrm{Tm}^{\mathrm{r}} \mathrm{Km}^{\mathrm{r}}$ determinant present on North American plasmids is flanked by inverted repeat sequences. Although these inverted repeats were some $0.65-\mathrm{kb}$ shorter than the repeats of $\operatorname{Tn} 4001$, they nonetheless shared homology on the basis of DNA-DNA hybridisation, suggesting the possibility of a common evolutionary pathway for Tn4001 and these "Tn4001-like" elements on the North American plasmids.

The transposition of Tn 4001 to multiple plasmid and chromosomal sites has been achieved in vitro, and transposon-specific sequences have been detected by DNA-DNA hybridisation on the chromosomes of $\mathrm{Gm}^{\mathrm{r}} \mathrm{Tm}^{\mathrm{r}} \mathrm{Km}^{\mathrm{r}} S$. aureus isolated from Australian hospitals (M. Gillespie, B. Lyon and R. Skurray, unpublished observation). Despite the fact that chromosomal $\mathrm{Gm}^{\mathrm{r}} \mathrm{Tm}^{\mathrm{r}} \mathrm{Km}^{\mathrm{r}}$ has not been reported in the USA, an indication that $\mathrm{Gm}^{\mathrm{r}}$ $\mathrm{Tm}^{\mathrm{r}} \mathrm{Km}^{\mathrm{r}}$ in strains of $S$. aureus from the USA is, or once was, transposable, is seen in the carriage of a determinant for AAC $\left(6^{\prime}\right)$ and $\mathrm{APH}\left(2^{\prime \prime}\right)$ activities by plasmids of different incompatibility groups (Gray et al., 1983). Attempts in this laboratory to demonstrate the transposition of the $\mathrm{Gm}^{\mathrm{r}} \mathrm{Tm}^{\mathrm{r}}$ $\mathrm{Km}^{\mathrm{r}}$ determinant from the North American plasmids by techniques used to identify Tn 4001 (Lyon et al., 1984b) have been unsuccessful, however, and it is possible that the inverted repeats with which this determinant is associated do not encode the necessary functions for transposition.

Although the Australian and North American $\mathrm{Gm}^{\mathrm{r}} \mathrm{Tm}^{\mathrm{r}} \mathrm{Km}^{\mathrm{r}}$ plasmids appear to be unrelated, it is significant that both plasmid families carry similar resistance determinants. Apart from mediating the common phenotype of $\mathrm{Gm}^{\mathrm{r}} \mathrm{Tm}^{\mathrm{r}} \mathrm{Km}^{\mathrm{r}}$, members of each family have been shown to carry determinants for $\mathrm{Eb}^{\mathrm{r}} \mathrm{Qa}^{\mathrm{r}}$ and to code for a $\beta$ lactamase. Hybridisation analysis has demonstrated that the $\mathrm{Eb}^{\mathrm{r}} \mathrm{Qa}^{\mathrm{r}}$ determinants of the Australian and USA plasmids are distinct (Gillespie and Skurray, 1986), although similar comparisons have shown that the $\beta$ lactamase determinants share substantial homology. From this evidence, one might conclude that, during the last decade, strains of $S$. aureus in Australian and USA hospitals faced very similar selection pressures, but that quite diverse plasmid vectors were chosen to disseminate the resistance genes required for survival.

\footnotetext{
We thank Jan Tennent for helpful discussions and Linda Messerotti and Khim Hoe for skilful technical assistance. This work was supported by a Project Grant from the National Health and Medical Research Council (Australia).
} 


\section{REFERENCES}

Archer G L, Johnston J L 1983 Self-transmissible plasmids in staphylococci that encode resistance to aminoglycosides. Antimicrobial Agents and Chemotherapy 24: 70-77.

Archer G L, Dietrick D R, Johnston J L 1985 Molecular epidemiology of transmissible gentamicin resistance among coagulase-negative staphylococci in a cardiac surgery unit. Journal of Infectious Diseases 151 : 243-251.

Asch D K, Goering R V, RuffE A 1984 Isolation and preliminary characterization of a plasmid mutant derepressed for conjugal transfer in Staphylococcus aureus. Plasmid 12: 197202.

Cohen M L, Wong E S, Falkow S 1982 Common R-plasmids in Staphylococcus aureus and Staphylococcus epidermidis during a nosocomial Staphylococcus aureus outbreak. Antimicrobial Agents and Chemotherapy 21 : 210-215.

Crossley K, Loesch D, Landesman B, Mead K, Chern M, Strate R 1979 An outbreak of infections caused by strains of Staphylococcus aureus resistant to methicillin and aminoglycosides. I. Clinical studies. Journal of Infectious Diseases 139: 273-279.

Daniels D L, Schroeder J L, Szybalski W, Sanger F, Blattner F R 1983 A molecular map of coliphage lambda. In: Hendrix R W et al. (eds) Lambda II, Cold Spring Harbor Laboratory, Cold Spring Harbor, NY p. 469.

Davis R W, Simon M, Davidson N 1971 Electron microscope heteroduplex methods for mapping regions of base sequence homology in nucleic acids. Methods in Enzymology $21: 413$ 428.

Dowd G, Cafferkey M, Dougan G 1983 Gentamicin and methicillin resistant Staphylococcus aureus in Dublin hospitals: molecular studies. Journal of Medical Microbiology 16: 129-138.

El Solh N, Fouace J M, Pillet J, Chabbert Y A 1981 Plasmid DNA content of multiresistant Staphylococcus aureus strains. Annales de Microbiologie 132B: 131-156.

Gillespie M T, Skurray R A 1986 Plasmids in multiresistant Staphylococcus aureus. Microbiological Sciences 3: 53-58.

Gillespie M T, May J W, Skurray R A 1984 Antibiotic susceptibilities and plasmid profiles of nosocomial methicillin-resistant Staphylococcus aureus: A retrospective study. Journal of Medical Microbiology 17: 295-310.

Goering R V, RuffE A 1983 Comparative analysis of conjugative plasmids mediating gentamicin resistance in Staphylococcus aureus. Antimicrobial Agents and Chemotherapy 24:450-452.

Gray G S, Huang RT-S, Davies J 1983 Aminocyclitol resistance in Staphylococcus aureus: Presence of plasmids and aminocyclitol-modifying enzymes. Plasmid 9: 147-158.

Hone R et al. 1981 Bacteraemia in Dublin due to gentamicin resistant Staphylococcus aureus. Journal of Hospital Infection 2: 119-126.

Horinouchi S, Weisblum B 1982 Nucleotide sequence and functional map of $\mathrm{pC194}$, a plasmid that specifies inducible chloramphenicol resistance. Journal of Bacteriology 150 : 815-825.

Jaffe H W, Sweeney H M, Weinstein R A, Kabins S A, Nathan C, Cohen S 1982 Structural and phenotypic varieties of gentamicin resistance plasmids in hospital strains of Staphylococcus aureus and coagulase-negative staphylococci. Antimicrobial Agents and Chemotherapy 21: 773-779.

Kayser F H, Homberger F, Devaud M 1981 Aminocyclitolmodifying enzymes specified by chromosomal genes in Staphylococcus aureus. Antimicrobial Agents and Chemotherapy 19: 766-772.

Le Goffic F, Martel A, Moreau N, Capmau M L, Soussy C J,
Duval J 1977 2"-O-Phosphorylation of gentamicin components by a Staphylococcus aureus strain carrying a plasmid. Antimicrobial Agents and Chemotherapy 12: 26-30.

Lyon B R, May J W, Skurray R A 1983 Analysis of plasmids in nosocomial strains of multiple-antibiotic-resistant Staphylococcus aureus. Antimicrobial Agents and Chemotherapy 23: 817-826.

Lyon B R, Iuorio J L, May J W, Skurray R A 1984a Molecular epidemiology of multiresistant Staphylococcus aureus in Australian hospitals. Journal of Medical Microbiology 17: 79-89.

Lyon B R, May J W, Skurray R A $1984 b$ Tn4001: a gentamicin and kanamycin resistance transposon in Staphylococcus aureus. Molecular and General Genetics 193: 554-556.

Lyon B R, Tennent J M, May J W, Skurray R A 1986 Trimethoprim resistance encoded on a Staphylococcus aureus gentamicin resistance plasmid: Cloning and transposon mutagenesis. FEMS Microbiology Letters 33: 189-192.

Maniatis T, Fritsch E F, Sambrook J 1982 Molecular cloning: a laboratory manual. Cold Spring Harbor Laboratory, Cold Spring Harbor, New York.

Martel A, Masson M, Moreau N, Le Goffic F 1983 Kinetic studies of aminoglycoside acetyltransferase and phosphotransferase from Staphylococcus aureus RPAL. Relationship between the two activities. European Journal of Biochemistry 133: $515-521$.

McDonnell R W, Sweeney H M, Cohen S 1983 Conjugational transfer of gentamicin resistance plasmids intra- and interspecifically in Staphylococcus aureus and Staphylococcus epidermidis. Antimicrobial Agents and Chemotherapy 23: 151-160.

Naidoo J, Noble W C, Weissmann A, and Dyke K G H 1983 Gentamicin-resistant staphylococci: genetics of an outbreak in a dermatology department. Journal of Hygiene 91 : 7-16.

Pavillard R et al. 1982 Epidemic of hospital-acquired infection due to methicillin-resistant Staphylococcus aureus in major Victorian hospitals. Medical Journal of Australia 1: 451454.

Price E H, Brain A, Dickson J A S 1980 An outbreak of infection with a gentamicin and methicillin resistant Staphylococcus aureus in a neonatal unit. Journal of Hospital Infection 1 : 221-228.

Ray A, Skurray R 1983 Cloning and polypeptide analysis of the leading region in F plasmid DNA transfer. Plasmid 9: 262272.

Sanger F et al. Nucleotide sequence of bacteriophage $\phi X 174$ DNA. Nature 265: 687-695.

Scott D F, Wood D O, Brownell G H, Carter M J, Best G K 1978 Aminoglycoside modification by gentamicin-resistant isolates of Staphylococcus aureus. Antimicrobial Agents and Chemotherapy 13: 641-644.

Shalita Z. Murphy E, Novick R P 1980 Penicillinase plasmids of Staphylococcus aureus: structural and evolutionary relationships. Plasmid 3: 291-311.

Smith G E, Summers M D 1980 The bidirectional transfer of DNA and RNA to nitrocellulose or diazobenzyloxymethylpaper. Analytical Biochemistry 109 : 123-129.

Smith H O 1980 Recovery of DNA from gels. Methods in Enzymology 65: 371-380.

Soussy C J, Bouanchaud D H, Fouace J, Dublanchet A, Duval J 1975 A gentamycin resistance plasmid in Staphylococcus aureus. Annales de Microbiologie 126B: 91-94.

Speller D C E et al. Epidemic infection by a gentamicin-resistant Staphylococcus aureus in three hospitals. Lancet 1 : 464-466.

Tennent J M, Lyon B R, Gillespie M T, May J W, Skurray R A 
1985 Cloning and expression of Staphylococcus aureus plasmid-mediated quaternary ammonium resistance in Escherichia coli. Antimicrobial Agents and Chemotherapy 27: 79-83.

Townsend D E, Grubb W B, Ashdown N 1983 Gentamicin resistance in methicillin-resistant Staphylococcus aureus. Pathology 15: 169-174.

Ubukata K, Yamashita N, Gotoh A, Konno M 1984 Purification and characterization of aminoglycoside-modifying enzymes from Staphylococcus aureus and Staphylococcus epidermidis. Antimicrobial Agents and Chemotherapy 25: 754-759.

Vogel L, Nathan C, Sweeney H M, Kabins S A, Cohen S 1978 Infections due to gentamicin-resistant Staphylococcus aureus strain in a nursery for neonatal infants. Antimicrobial Agents and Chemotherapy 13: 466-472.

Wood D O, Carter M J, Best G K 1977 Plasmid-mediated resistance to gentamicin in Staphylococcus aureus. Antimicrobial Agents and Chemotherapy 12: 513-517. 